\title{
Antiapoptotic Seminal Vesicle Protein IV Induces Histamine Release from Human FceRI+ Cells
}

\author{
Nella Prevete ${ }^{a} \quad$ Francesca Wanda Rossi $^{a} \quad$ Massimo Triggiani $^{a} \quad$ Gianni Marone $^{a}$ \\ Amato de Paulis $^{a}$ Vittoria Metaforab Salvatore De Mariac Maria Cartenì ${ }^{c}$ \\ Raffaele Ragone $^{d}$ Gianpietro Ravagnan ${ }^{\mathrm{e}}$ Salvatore Metafora ${ }^{\mathrm{b}}$ \\ ${ }^{a}$ Division of Clinical Immunology and Allergy, University of Naples Federico II, b Institute of Genetics and \\ Biophysics 'Adriano Buzzati-Traverso', CNR, 'Department of Experimental Medicine, Medical School, II University \\ of Naples, and 'Department of Biochemistry and Biophysics, Medical School, II University of Naples, Naples, and \\ 'Department of Environmental Sciences, Ca' Foscari Venezia University, Venice, Italy
}

\section{Key Words}

Protein SV-IV • Mast cells · Basophils $\cdot$ FceRI receptor $\cdot$ Histamine $\cdot$ Degranulation $\cdot$ Blastocyst implantation

\begin{abstract}
Background: Seminal vesicle protein number 4 (SV-IV) is a small, basic, multifunctional, intrinsically disordered secretory protein synthesized in large amounts by rat seminal vesicle epithelium under androgen transcriptional control. SVIV-immunorelated proteins occur in other rat tissues and in humans. Methods: The in vitro effect of SV-IV on human $\mathrm{Fc} \varepsilon \mathrm{RI}+$ cells was investigated by standard immunologic, biochemical and molecular biology procedures. Results: SVIV-induced histamine release from human basophils and lung mast cells without any influence on leukotriene $C_{4}$ release and cell migration. The histamine release rate was slower compared with that induced by anti-IgE, the temperature dependence of the event being similar. SV-IV-induced histamine release was $\mathrm{Ca}^{2+}$-dependent, suggesting a physiological interaction of the protein with FceRI+ cells. SV-IV and anti-IgE acted synergistically on the histamine release.
\end{abstract}

\begin{tabular}{ll}
\hline KARGER & ( 2009 S. Karger AG, Basel \\
Fax +4161306 1234 34 -2438/09/0000-0000\$26.00/0 \\
$\begin{array}{l}\text { E-Mail karger@karger.ch } \\
\text { www.karger.com }\end{array}$ & $\begin{array}{l}\text { Accessible online at: } \\
\text { www.karger.com/iaa }\end{array}$
\end{tabular}

SV-IV did not induce de novo synthesis of cytokines and growth factors (transforming growth factor- $\beta_{1}$, interleukin10 , interleukin-13, tumor necrosis factor- $\alpha$, vascular endothelial growth factor A) in FceRI+ cells. Conclusions: SV-IV protein induces in human $\mathrm{Fc \varepsilon RI}+$ cells the release of histamine, a proinflammatory, antiapoptotic and immunosuppressive biogenic amine. These data: (1) are consistent with the antiapoptotic and immunosuppressive properties of SVIV; (2) confirm a regulatory feature of SV-IV on mammal inflammatory reactivity by either inhibiting the arachidonate cascade pathway or stimulating proinflammatory cytokine release from lymphocyte/monocytes and histamine from $\mathrm{Fc} \varepsilon \mathrm{RI}+$ cells; (3) raise the possibility of a protective role of SVIV on implanting hemiallogenic blastocysts against maternal reactive oxygen species and immunological attacks at the uterine implantation site. Copyright @ 2009 S. Karger AG, Basel

A.d.P., F.W.R., G.M., N.P., S.D.M., S.M. and V.M. contributed equally to this work. 


\section{Introduction}

Seminal vesicle protein No. 4 (SV-IV), according to its mobility in SDS-PAGE; precursor UniProtKB/Swiss-Prot ID, SVS4_RAT; accession No. P02783) is a purified and extensively characterized $\left(\mathrm{M}_{\mathrm{r}}=9,758 ; \mathrm{pI}=8.9\right)$ multifunctional secretory protein. It is synthesized by the rat seminal vesicle epithelium under androgen transcriptional control [1-5] and is encoded by a gene sequenced, cloned, and expressed in Escherichia coli [6-9]. Its polypeptide chain is a thermostable, intrinsically disordered [10-12] and highly flexible molecule. In aqueous solution, it behaves as a concentration-dependent self-associating system (monomer $\rightleftarrows$ dimer $\rightleftarrows$ trimer equilibrium) in which the biologically active configuration is monomeric and the inactive one is trimeric $[11,12]$. In the range of physiological concentrations $(2-48 \mu \mathrm{M})[11,13]$, its biological properties are modulated by a supramolecular equilibrium in which the trimeric form competes with the monomeric one for binding to a variety of cell targets [11]. SV-IV-immunorelated proteins occur in several rat tissues (uterus, lung, liver, brain), as well as in human seminal fluid and seminal vesicle secretion [14-16].

SV-IV exerts a non-species-specific inhibitory activity on inflammation, cell-mediated and humoral immunity, and apoptosis [13, 17-25]. In addition, it possesses a stimulatory effect on purified peroxidases $[25,26]$ and protects cells against oxidative-stress-induced damage, by acting as an indirect reactive-oxygen-species scavenger [25]. Besides, SV-IV immunosuppressive properties suggest a defensive role against maternal immunological attack of hemiallogenic implanting blastocysts [11, 19, 23, $25,27]$. The anti-inflammatory effect of the protein is related to phospholipase $\mathrm{A}_{2}\left(\mathrm{PLA}_{2}\right)$ inhibition, while its immunomodulatory activity is generated by interference with macrophage-T cell cooperation (modulation of cytokine production; inhibition of macrophage antigen presentation and $\mathrm{T}$ cell activation) [13, 19-24, 28].

SV-IV induces the release of cytokines, i.e. interferon$\gamma($ IFN- $\gamma$ ), granulocyte macrophage colony-stimulating factor (GM-CSF), tumor necrosis factor- $\alpha$ (TNF- $\alpha$ ), interleukin-6 (IL-6), from human isolated resting lymphocytes and monocytes with proinflammatory features in contrast to its known anti-inflammatory properties. Prompted by this observation, we investigated whether SV-IV exerted any stimulatory or inhibitory activity on human cells (mast cells and basophils) positive for highaffinity receptor I for IgE (FceRI+ cells). The effects of SV-IV on these cells have not yet been explored by our group.
Mast cells and basophils are effectors of allergic reactions. They express high-affinity tetrameric Fc receptors $\left(\alpha / \beta / \gamma_{2}\right)$ for IgE (FceRIs) on their surface and contain histamine-rich granules in their cytosol. These two attributes distinguish these cells from all other human cell types and explain their unique role in allergic inflammation. The surface of FceRI+ cells is coated with IgE molecules adsorbed from the circulation and serving as receptors for specific antigens. The binding of antigens to IgE activates these cells, inducing their degranulation with release of granule content (e.g., histamine, proteinases, cytokines, chemokines and growth factors) into the surrounding medium [29].

Mast cells are marrow-derived, tissue-resident elements essential for IgE-mediated inflammatory reactions. They secrete a wide variety of biologically active substances (mediators) when stimulated by immunological (e.g., anti-IgE and anti-FceRI) or nonimmunological secretagogue stimuli (e.g. lectins, N-formylmethionylleucyl-phenylalanine, calcium ionophores and $\mathrm{PLA}_{2}$ ). FceRI+ cells can be activated directly by pathogens (bacteria, viruses and parasites), by soluble products (e.g., proteins, oligopeptides and toxins) derived from these pathogens or other organic sources. Mediators released by mast cells have been classified as: (a) preformed mediators, stored in cytoplasmic granules (e.g., histamine, proteoglycans and various enzymes); (b) lipid mediators synthesized de novo [e.g., prostaglandin $\mathrm{D}_{2}$ and leukotriene $\left.\mathrm{C}_{4}\left(\mathrm{LTC}_{4}\right)\right]$, cytokines, chemokines, and growth factors [30]. These mediators, in addition to proinflammatory activity [30], may also have anti-inflammatory or immunosuppressive properties [e.g., interleukin-10 (IL$10)$, transforming growth factor- $\left.\beta_{1}\left(\mathrm{TGF}-\beta_{1}\right)\right][31,32]$ and, frequently, promote local degradation or remodeling of inflamed tissues [33].

Basophils are circulating marrow-derived cells that share many properties with tissue mast cells, although they are a distinct cell lineage and are not found in normal tissues. These cells express IL-4 and IL-13 mRNA, infiltrate the sites of allergic inflammation in asthmatic responses $[29,34]$, and are detectable in inflammatory infiltrates of Helicobacter-pylori-induced gastritis [35].

The present study aimed at investigating the effect of SV-IV on resting or anti-IgE-stimulated FceRI+ cells. This treatment induced the release of histamine, a proinflammatory, antiapoptotic, and immunosuppressive biogenic amine [36-41], not associated with the secretion of immunosuppressive or proinflammatory cytokines or growth factors synthesized de novo. 
These results: (a) are in line with the antiapoptotic and immunosuppressive properties of SV-IV $[13,17,19-24$, 28]; (b) confirm a modulatory activity of this protein on mammal inflammation reactivity by either inhibiting the arachidonate cascade pathway $[19,21]$ or stimulating the release of proinflammatory cytokines from lymphocytes/monocytes [13] and histamine from FceRI+ cells; (c) raise the possibility of a protective role of SV-IV on implanting hemiallogenic blastocyst against reactive oxygen species and maternal immunological attacks at the uterine implantation site in concert with other local immunosuppressive cells (mast cells and CD4+CD25+ FoxP3+ regulatory T cells), cytokines (TGF- $\beta_{1}$, IL-10), and antiapoptotic factors (leukemia inhibitory factor, heme oxygenase 1, peroxidases and histamine).

\section{Materials and Methods}

Chemicals

The following reagents were purchased: $60 \% \mathrm{HClO}_{4}$ (Baker Chemical, Deventer, The Netherlands); human serum albumin, PIPES (Sigma, St. Louis, Mo., USA); FCS, TRIzol, and murine Moloney leukemia virus transcriptase (Life Technologies, Grand Island, N.Y., USA); RPMI-1640 (Flow Laboratories, Irvine, UK); dextran 70 and Percoll (Pharmacia, Uppsala, Sweden); PCR kit (Promega Corporation, USA). Rabbit polyclonal IgG from nonimmunized animals was obtained from Sigma. Rabbit anti-human IgE Ab was a gift from Drs. Teruko and Kimishige Ishizaka (La Jolla Institute for Allergy and Immunology, La Jolla, Calif., USA). All other reagents were of the highest purity commercially available.

\section{Buffers}

The PIPES buffer contains $25 \mathrm{~mm}$ PIPES (pH 7.4), $110 \mathrm{~mm}$ $\mathrm{NaCl}, 5 \mathrm{mM} \mathrm{KCl}$, and is referred to as P. In addition to P, PCG contains, $5 \mathrm{mM} \mathrm{CaCl}_{2}$ and $1 \mathrm{~g} / \mathrm{l} \mathrm{D}$-glucose [42]. In addition to $\mathrm{P}$, PACGM contains $3 \%$ human serum albumin, $1 \mathrm{mM} \mathrm{CaCl}_{2}, 1 \mathrm{~g} / 1$ D-glucose, and $0.25 \mathrm{~g} / \mathrm{MgCl}_{2} \cdot 6 \mathrm{H}_{2} \mathrm{O}$ ( $\left.\mathrm{pH} 7.4\right)$. In addition to $\mathrm{P}$, PGMD contains $0.25 \mathrm{~g} / 1 \mathrm{MgCl}_{2} \cdot 6 \mathrm{H}_{2} \mathrm{O}, 10 \mathrm{mg} / \mathrm{l} \mathrm{DNase}$, and $1 \mathrm{~g} / \mathrm{l}$ gelatin (pH 7.4). PBS contains $8 \mathrm{~g} / \mathrm{l} \mathrm{NaCl}, 1.15 \mathrm{~g} / \mathrm{l} \mathrm{Na} \mathrm{HPO}_{4}, 200$ $\mathrm{mg} / \mathrm{l} \mathrm{KCl}$, and $200 \mathrm{mg} / \mathrm{K} \mathrm{KH}_{2} \mathrm{PO}_{4}$, pH 7.4.

\section{Purification of SV-IV}

SV-IV was purified to homogeneity from the seminal vesicle secretion of adult rats (Fisher-Wistar strain) according to a previously published technique [1]. The purity of the protein was evaluated by $15 \%$ PAGE under denaturing and nondenaturing conditions, amino acid composition analysis, fingerprinting technique, and fast atom bombardment mass spectrometry [15, 43]. Neither lipopolysaccharide nor TNF, as determined by specific biological assays $[44,45]$, was present in the SV-IV preparations. The concentration of purified SV-IV was measured by its molar extinction coefficient at $276 \mathrm{~nm}\left(4,100 \mathrm{M}^{-1} \cdot \mathrm{cm}^{-1}\right)$, calculated on the basis of the tyrosine and phenylalanine residues present in the SVIV polypeptide chain [11].

\section{Mast Cell Culture}

Human mast cell line (HMC-1) was donated by Dr. J.H. Butterfield (Mayo Clinic, Rochester, Minn., USA); cells were maintained in a humidified incubator $\left(37^{\circ} \mathrm{C}, 5 \% \mathrm{CO}_{2}\right)$ in suspension culture at a concentration of $3-9 \times 10^{5}$ cells $/ \mathrm{ml}$ of Iscove's Modified Dulbecco's Medium supplemented with 10\% FCS, $2 \mathrm{mM}$ L-glutamine, and 1.2 $\mathrm{mm}$ monothioglycerol [46].

\section{Cell Purification}

Basophils

Basophils were purified from peripheral blood of healthy volunteers, aged 20-39 years (33.6 \pm 4.9 years) and negative for HIV1 and HIV-2 antibodies. Buffy-coat cell packs were provided by the Immunohematology Service (University of Naples Federico II). Informed consent, according to the guidelines of the University of Naples Federico II institutional review board for the use of humans in research, was obtained. Cells were reconstituted in PBS containing $0.5 \mathrm{~g} / \mathrm{l}$ human serum albumin and $3.42 \mathrm{~g} / \mathrm{l}$ sodium citrate and loaded onto a countercurrent elutriator (model J2-21; Beckman, Fullerton, Calif., USA). Several fractions were collected, and fractions containing basophils in large numbers $\left(>20 \times 10^{6}\right.$ basophils) and of good purity $(>15 \%)$ were enriched by discontinuous Percoll gradients. Basophils were further purified to near homogeneity ( $>98 \%$ ) by removing B cells, monocytes, NK cells, dendritic cells, erythrocytes, platelets, neutrophils, eosinophils, and T cells using a cocktail of hapten-conjugated CD3, CD7, CD14, CD15, CD16, CD36, CD45RA, and anti-HLA-DR antibodies and MACS MicroBeads (Miltenyi Biotec, Bergisch Gladbach, Germany) coupled to an anti-hapten monoclonal antibody. The magnetically labeled cells were depleted by retaining them on a MACS column in the magnetic field of the MidiMACS (Miltenyi Biotec). Yields ranged from 3 to $10 \times 10^{6}$ basophils, with purity usually $>98 \%$, as assessed by basophil staining with Alcian blue and counting in a Spiers-Levy eosinophil counter [35].

Human Lung Mast Cells

Lung tissue was obtained from patients undergoing thoracotomy and lung resection. Macroscopically normal parenchyma was dissected free from pleura, bronchi, and blood vessels and minced into a single-cell suspension as previously described [42]. Yields with this technique ranged between $3 \times 10^{6}$ and $18 \times 10^{6}$ mast cells, and purities were between 1 and $8 \%$. Human lung mast cells (HLMCs) were purified first by countercurrent elutriation (J2/21; Beckman) and then by discontinuous Percoll density gradient as previously reported [42]. Mast cells were further purified to near homogeneity by positive selection using an anti-CD117 monoclonal antibody conjugated to magnetic beads and retaining labeled cells on a selection column (MACS system; Miltenyi Biotec). The final preparations contained $>95 \%$ viable cells, as assessed by the trypan blue exclusion method and a lactate dehydrogenase (LDH) assay, with a mast cell purity higher than $98 \%$.

\section{Chemotaxis Assay}

Basophil and mast cell chemotaxis experiments were carried out using a modified Boyden chamber technique. Briefly, $25 \mu \mathrm{l}$ of either PACGM buffer or various concentrations of chemoattractants in the same buffer were added in triplicate into the lower compartment of a 48-well microchemotaxis chamber (Neuroprobe, Cabin John, Md., USA). The lower compartments were covered with polycarbonate membranes of $5.0 \mu \mathrm{m}$ pore size (ba- 
Table 1. Sequence of primers used in the real-time RT-PCR analysis

\begin{tabular}{llll}
\cline { 2 - 4 } Table 1. Sequence of primers used in the & Genes & Oligonucleotide sense $\left(5^{\prime}-3^{\prime}\right)$ & Oligonucleotide antisense $\left(5^{\prime}-3^{\prime}\right)$ \\
\cline { 2 - 4 } & VEGF-A & GTGAATGCAGACCAAAGAAAG & AAACCCTGAGGGAGGCTC \\
IL-10 & CTGCCTAACATGCTTCGAGA & TGAGGGTCTTCAGGTTCTCC \\
TGF- $\beta$ & AGCCTGAGGCCGACTACTAC & GAGGTATCGCCAGGAATTGT \\
IL-13 & CCTCAATCCTCTCCTGTTGG & CCACCTCGATTTGGTGTCT \\
TNF- $\alpha$ & GACAAGCCTGTAGCCCATGT & CTGAGTCGGTCACCCTTCTC \\
GAPDH & GCCAAAGGGTCATCATCTC & GTAGAGGCAGGGATGATGTTC \\
\hline
\end{tabular}

sophils) or with a two-filter sandwich constituted by 5 - $\mu \mathrm{m}$ (lower) and $8-\mu \mathrm{m}$ pore size (upper) polycarbonate membranes (mast cells); Nucleopore, Pleasanton, Calif., USA) [35]. Fifty microliters of cell suspension $\left(5 \times 10^{4} /\right.$ well $)$ resuspended in PACGM were added into the upper compartment. The chemotactic chamber was incubated for $1 \mathrm{~h}$ (basophils) or $3 \mathrm{~h}$ (mast cells) at $37^{\circ} \mathrm{C}$ in a humidified incubator with $5 \% \mathrm{CO}_{2}$ (automatic $\mathrm{CO}_{2}$ incubator, model 160 IR, ICN/Flow Laboratories). At the end of basophil incubation, the membranes were removed, washed with PBS on the upper side, fixed, and stained with May-Grünwald/Giemsa. When mast cells were used, the upper polycarbonate filter was discarded, while the lower nitrate cellulose filter was fixed in methanol, stained with Alcian blue, and then mounted on a microscope slide with Cytoseal (Stephen Scientific, Springfield, N.J., USA). Basophil and mast cell chemotaxis was quantified microscopically by counting the number of cells attached to the surface of the $5-\mu \mathrm{m}$ filter. In each experiment, 10 fields/triplicate filter were measured at $40 \times$ magnification.

Checkerboard analyses were performed to discriminate between chemotaxis and chemokinesis (spontaneous nondirected migration) of cells. In these experiments, cells were placed in the upper chemotactic chambers and various concentrations of chemoattractants or buffer were added to the upper or lower wells or to both. Chemokinesis was determined in the absence of chemoattractants or when the latter were added to both the lower or upper chambers. The cell migratory response to SV-IV to chemotactic stimuli was largely due to chemotaxis and not to chemokinesis. Indeed, a checkerboard analysis, in which chemoattractants above and below the filters varied resulted in significant migration only when there was a gradient of the factor below the filters.

\section{Histamine Release Evaluation}

Basophils $\left(6 \times 10^{4}\right.$ basophils/test tube $)$ or mast cells $\left(3 \times 10^{4}\right.$ cells/test tube) were resuspended in PCG, and $0.1 \mathrm{ml}$ of cell suspension was placed in $12 \times 75-\mathrm{mm}$ polyethylene test tubes (Sarstadt, Princeton, N.J., USA) and warmed to $37^{\circ} \mathrm{C}$. One hundred microliters of each prewarmed releasing stimulus was added and incubation was continued at $37^{\circ} \mathrm{C}$ for $45 \mathrm{~min}$. PCG [47] was used in these experiments. At the end of this step, the reaction was stopped by centrifugation $\left(1,000 \mathrm{~g}, 22^{\circ} \mathrm{C}, 2 \mathrm{~min}\right)$, and the cell-free supernatants were stored at $-20^{\circ} \mathrm{C}$ for subsequent evaluation of the histamine level with an automated fluorimetric technique [47]. Total histamine content was assessed by lysing the cells with $2 \% \mathrm{HClO}_{4}$ before centrifugation. To calculate histamine release as a percentage of total cellular histamine, the spontaneous release of histamine from basophils and HLMCs (2-14\% of the total cellular histamine) was subtracted from both the numerator and the denominator [47]. The percentage of histamine release was calculated according to the equation $[(\mathrm{A}-\mathrm{B}) /(\mathrm{T}-\mathrm{B})] \times 100$, where $\mathrm{A}$ is the sample, $\mathrm{B}$ is the spontaneous histamine release, and $\mathrm{T}$ is the total histamine content. All values are based on means of duplicate or triplicate determinations. Replicates differed in histamine content by $<10 \%$.

\section{Cytokine and Vascular Endothelial Growth Factor A mRNA}

\section{Evaluation by Real-Time PCR}

Total RNA from HMC-1 cells was extracted by using the SV 96 total RNA isolation system (Promega, Milan, Italy) and treated with RNase-free DNase I. Five micrograms of RNA were retrotranscribed as previously described [48]. cDNA was titrated for GAPDH mRNA and the expression of TGF- $\beta_{1}$, IL-10, IL-13, TNF$\alpha$ and vascular endothelial growth factor A (VEGF-A) mRNA was evaluated by real-time RT-PCR. The latter was performed with the iCycler (Bio-Rad) by using the PE SYBR Green PCR kit (Applied Biosystems, Foster City, Calif., USA). Target-specific primers for GAPDH and analyzed cytokines suitable for real-time PCR were used (table 1). After an initial denaturation step at $95^{\circ} \mathrm{C}$ for $10 \mathrm{~min}$, amplification was performed with 40 cycles of denaturation $\left(95^{\circ} \mathrm{C}\right)$ for $30 \mathrm{~s}$, annealing $\left(56.5^{\circ} \mathrm{C}\right)$ for $30 \mathrm{~s}$, and elongation $\left(72^{\circ} \mathrm{C}\right)$ for $30 \mathrm{~s}$. PCR efficiency was evaluated by serial dilutions of template cDNA, and the melting curve data were collected to verify PCR specificity. Each cDNA sample was analyzed in triplicate and the corresponding no-RT mRNA sample was included as a negative control. The mRNA signal for the cytokines in each sample was normalized to GAPDH mRNA. The data were analyzed by the iCycler iQ software (Bio-Rad) and the mRNA changes in different conditions were expressed as the ratio versus GAPDH.

TGF- $\beta_{1}$ and VEGF-A Release Assessment

For the evaluation of TGF- $\beta_{1}$ and VEGF-A release we incubated HMC- $1\left(37^{\circ} \mathrm{C}\right.$ for $16 \mathrm{~h}$ in Iscove's Modified Dulbecco's Medium containing $5 \% \mathrm{FBS})$ and basophils $\left(37^{\circ} \mathrm{C}\right.$ for $4 \mathrm{~h}$ in RPMI containing $5 \%$ FBS) with SV-IV $(1-30 \mu \mathrm{M})$. TGF- $\beta_{1}$ and VEGF-A release in the supernatant was measured by ELISA (R\&D Systems, Minneapolis, Minn., USA) in duplicate determinations and the results were normalized for the protein content of each well.

\section{Evaluation of CD203c on FceRI+ Cell Surface}

Staining was performed at $4^{\circ} \mathrm{C}$ for $30 \mathrm{~min}$ with $10 \mu \mathrm{l} / 200 \mu \mathrm{l}$ cell suspensions of the marker antibodies: anti-CD203c-PE and anti-IgE-FITC. The negative controls consisted of isotypematched, directly conjugated nonspecific antibodies. Cells were 


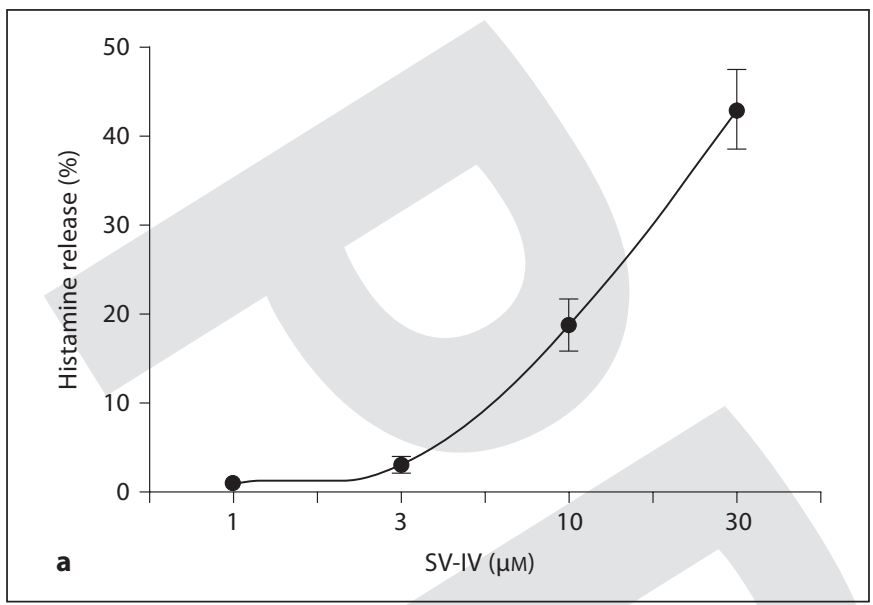

Fig. 1. a Effect of increasing concentrations (1-30 $\mu \mathrm{M})$ of SV-IV on histamine release from human basophils: cells were challenged $\left(45 \mathrm{~min}\right.$ at $\left.37^{\circ} \mathrm{C}\right)$ with the indicated concentrations of SV-IV; histamine release was calculated as percentage of total cellular histamine; the spontaneous release of histamine from basophils (2$14 \%$ of the total cellular histamine) was subtracted from each determination. b Effect of increasing concentrations $(1-30 \mu \mathrm{M})$ of

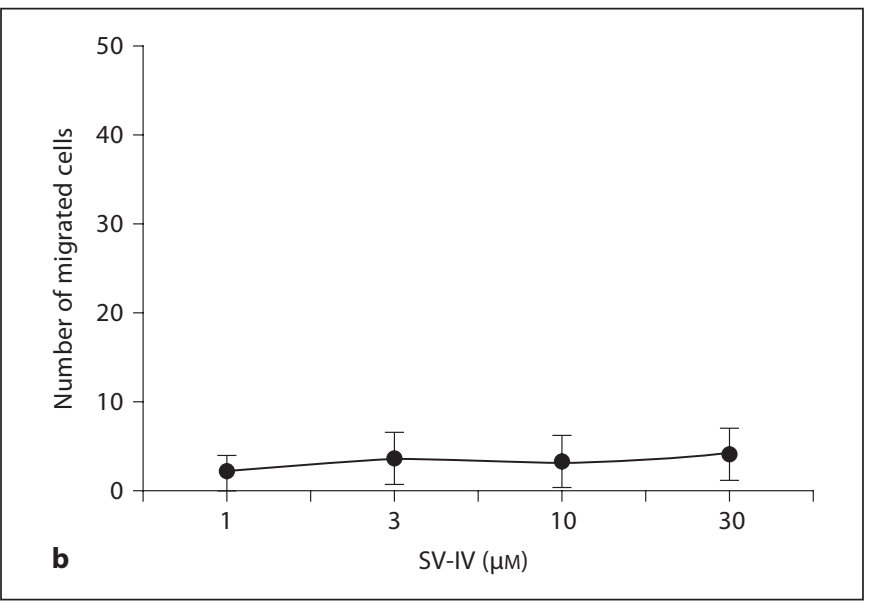

SV-IV on the chemotaxis of human basophils. Cells were allowed to migrate for $1 \mathrm{~h}$ toward the indicated concentrations of SV-IV at $37^{\circ} \mathrm{C}$ in a humidified incubator in the presence of $5 \% \mathrm{CO}_{2}$. Values are the means \pm SEM of 6 experiments with different cell preparations. Further experimental details are indicated in Materials and Methods. washed and analyzed with a FACSCalibur cytofluorimeter using CellQuest software (BD Bioscience, San Ferdinando, Calif., USA). A total of $10^{4}$ events for each sample were acquired in all cytofluorimetric analyses.

\section{Lactate Dehydrogenase Assay}

$\mathrm{LDH}$ release at the end of the incubations served as an index of cytotoxicity. It was measured in cell-free supernatants using a commercially available kit (Sigma-Aldrich) [35].

Statistics

The results are expressed as means \pm SEM. Values from groups were compared using the paired Student's t test. Differences were considered significant when $\mathrm{p}<0.05$.

\section{Results}

\section{SV-IV Treatment of Basophils Induces Histamine \\ Release but Not Cell Migration}

In a first group of experiments, we assessed the effect of increasing concentrations of SV-IV on histamine release from purified peripheral blood basophils ( $>98 \%$ pure) obtained from normal human donors. Basophils were incubated for $30 \mathrm{~min}$ at $37^{\circ} \mathrm{C}$ in the presence of progressively increasing concentrations of SV-IV $(1-30 \mu \mathrm{M})$. Following incubation, the cells were eliminated by centrifugation and histamine released in supernatant was evaluated as indicated in Materials and Methods. In a se- ries of 6 experiments, treatment with SV-IV induced a significant concentration-dependent release of histamine $(3.2 \pm 0.8 \%$ at $1 \mu \mathrm{M}$ SV-IV; $43.7 \pm 4.6 \%$ at $30 \mu \mathrm{MSV}$-IV $)$ (fig. 1a).

In other experiments, the effect of SV-IV on basophil chemotaxis was studied with a modified Boyden chamber [42]. The results from 5 experiments demonstrated that SV-IV $(1-30 \mu \mathrm{M})$ was unable to promote basophil migration (fig. 1b), in line with the known ability of SVIV to inhibit chemotaxis in human leukocytes [20].

The concentrations of SV-IV used did not induce spontaneous LDH release from basophils (data not shown).

\section{Characteristics (Time Course, Temperature and Extracellular-Ca ${ }^{2+}$ Dependence) of SV-IV-Induced Histamine Release}

We first compared the kinetics (1-45 $\mathrm{min}$ ) of histamine release induced by $30 \mu \mathrm{M} \mathrm{SV}-\mathrm{IV}$ and $0.6 \mathrm{nM}$ antiIgE in basophils. The time course of histamine release induced by SV-IV was slow, reaching a maximum at about 45 min after stimulus addition. In contrast, antiIgE-induced histamine release was significantly faster, being complete after only $15 \mathrm{~min}$ (fig. 2a). The difference between SV-IV and anti-IgE histamine-releasing rates implies possible differences in the release mechanism elicited by the two different stimuli. 

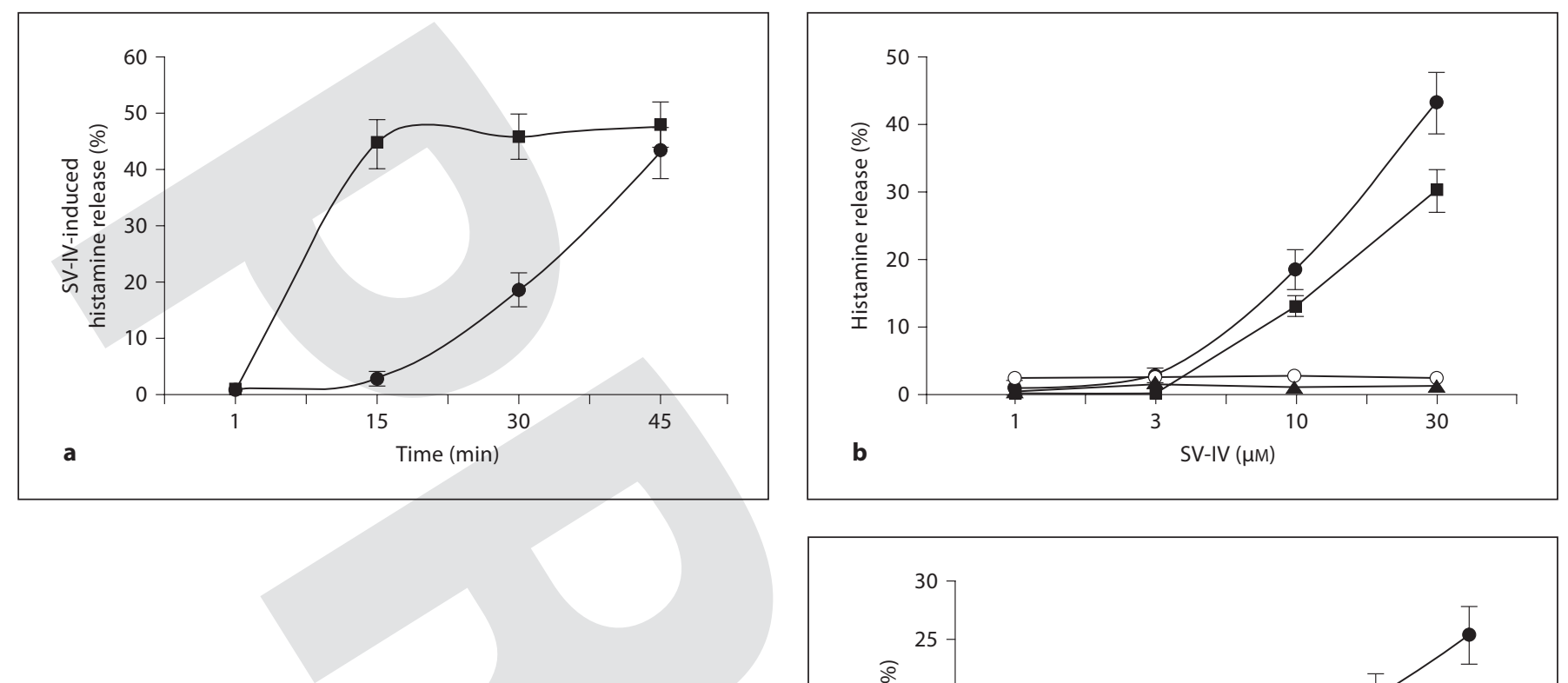

Fig. 2. a Kinetics of histamine secretion from human basophils induced at $37^{\circ} \mathrm{C}$ by anti-IgE $(0.6 \mathrm{nn})(\boldsymbol{\square})$ and SV-IV $(30 \mu \mathrm{M})(\bullet)$ : each point represents the mean of duplicate determinations from a typical experiment out of 3 performed with similar results. b Effect of increasing concentrations of SV-IV on histamine release from basophils incubated for $60 \mathrm{~min}$ at $37^{\circ} \mathrm{C}(\bullet), 30^{\circ} \mathrm{C}(\boldsymbol{\square})$, $22^{\circ} \mathrm{C}(\bigcirc)$, or $4^{\circ} \mathrm{C}(\boldsymbol{\Delta})$ : each point represents the mean of duplicate determinations from a typical experiment out of 3 performed with similar results. c Effect of various concentrations of extracellular $\mathrm{Ca}^{2+}$ on histamine release induced by SV-IV $(10 \mu \mathrm{M})$ from human basophils incubated for $60 \mathrm{~min}$ at $37^{\circ} \mathrm{C}$.

The temperature dependence of histamine-releasing activity of SV-IV on basophils was studied by stimulating these cells at $37,30,22$, and $4^{\circ} \mathrm{C}$. Figure $2 \mathrm{~b}$ shows that the SV-IV-induced response was abolished by lowering the incubation temperature from $37^{\circ} \mathrm{C}$ to $22^{\circ} \mathrm{C}$ or $4^{\circ} \mathrm{C}$, a decrease of about $30 \%$ having been observed at $30^{\circ} \mathrm{C}$. Similar results were obtained in other 2 identical experiments.

The effect of increasing concentrations of extracellular $\mathrm{Ca}^{2+}(0-5.0 \mathrm{mM})$ on histamine-releasing activity of basophils in the presence of $10 \mu \mathrm{M} \mathrm{SV-IV} \mathrm{was} \mathrm{also} \mathrm{inves-}$ tigated. The $\mathrm{Ca}^{2+}$ increase progressively enhanced the SV-IV-induced histamine release (fig. 2c). This finding indicates a physiological interaction between SV-IV and basophils. It is worth noting that all the experiments reported in this study were conducted with physiologic concentrations of extracellular $\mathrm{Ca}^{2+}(2 \mathrm{mM})$.

SV-IV Does Not Induce $\mathrm{LTC}_{4}$ Release from Basophils

The immunologic activation of human basophils, in addition to the secretion of preformed histamine, leads to

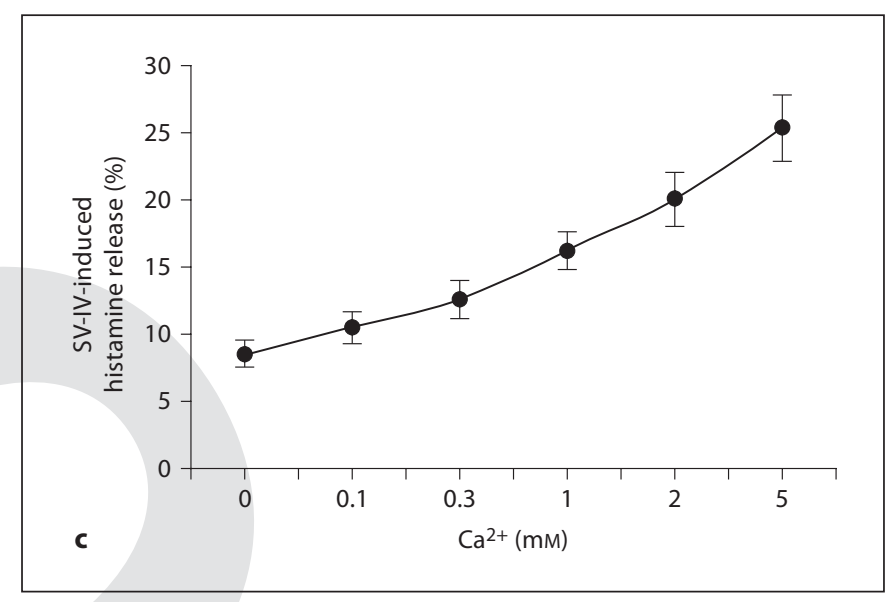

de novo synthesis and release of $\mathrm{LTC}_{4}$ through the 5lipoxygenase pathway. In a series of 4 experiments, we compared the effects of 1-30 $\mu \mathrm{M}$ SV-IV and 0.18-6 $\mathrm{nM}$ anti-IgE on the release of $\mathrm{LTC}_{4}$ from basophils. SV-IV did not induce the release of $\mathrm{LTC}_{4}$ from basophils. In contrast, anti-IgE markedly stimulated the release of $\mathrm{LTC}_{4}$ (data not shown). This finding suggests that SV-IV could act as an incomplete secretagogue being able to release only histamine and not de-novo-synthesized mediators.

\section{Synergy between SV-IV and Anti-IgE on Histamine} Release from Basophils

Anti-IgE, which induces histamine release by crosslinking cell surface IgE, was tested for synergy with SVIV. Figure 3 shows that SV-IV promoted anti-IgE-induced histamine release from basophils. More in details, treatment $\left(10 \mathrm{~min}\right.$ at $\left.37^{\circ} \mathrm{C}\right)$ of these cells with $1-30 \mu \mathrm{M}$ SV-IV resulted in marked enhancement of histamine release by using optimal concentrations of anti-IgE $(0.6 \mathrm{nM})$ (fig. 3). The SV-IV/anti-IgE synergy demonstrated by 


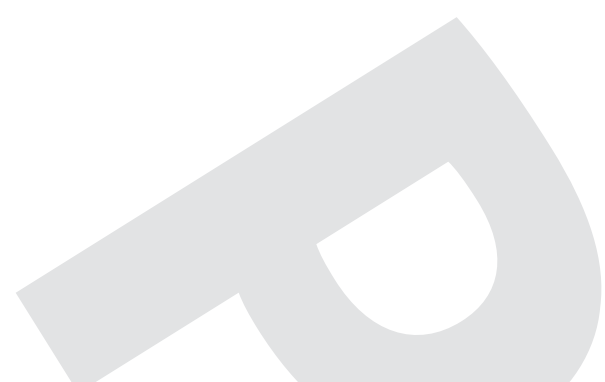

Fig. 3. Effect of preincubation $\left(10 \mathrm{~min}\right.$ at $\left.37^{\circ} \mathrm{C}\right)$ with increasing concentrations $(1-30 \mu \mathrm{M})$ of SV-IV on histamine release from human basophils induced by anti-lgE $(0.6 \mathrm{nM})$. Each point represents the mean of duplicate determinations from a typical experiment out of 5 performed with similar results.

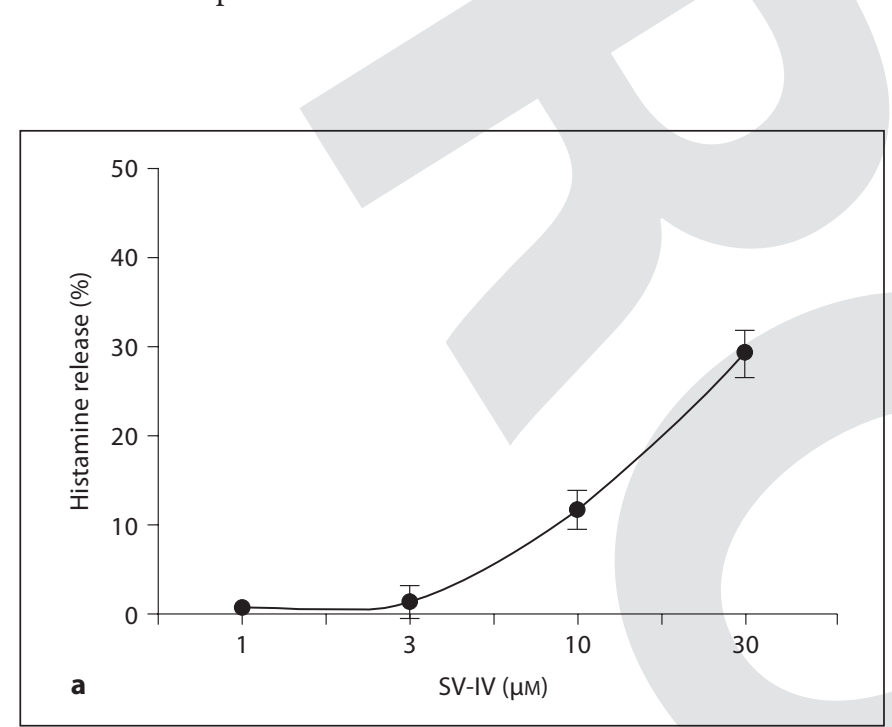

Fig. 4. a Effect of increasing concentrations (1-30 $\mu \mathrm{M})$ of SV-IV on histamine release from HLMC: cells were challenged (45 min at $37^{\circ} \mathrm{C}$ ) with the indicated concentrations of SV-IV; histamine release was calculated as percentage of total cellular histamine; the spontaneous release of histamine from human mast cells (2$14 \%$ of the total cellular histamine) was subtracted from each de-

these data indicates a possible molecular cross-talk between the two histamine-releasing mechanisms. Further experiments are warranted to elucidate the SV-IV histamine-releasing mechanism.

\section{SV-IV Alone or in Synergy with Anti-IgE Induces Histamine Release from HLMCs}

The heterogeneity of human basophils and mast cells prompted us to verify whether SV-IV could also induce histamine release from primary mast cells, easily purified in a sample from human resected lungs. For histamine release experiments, we used primary mast cells, a

SV-IV Induces Histamine Release
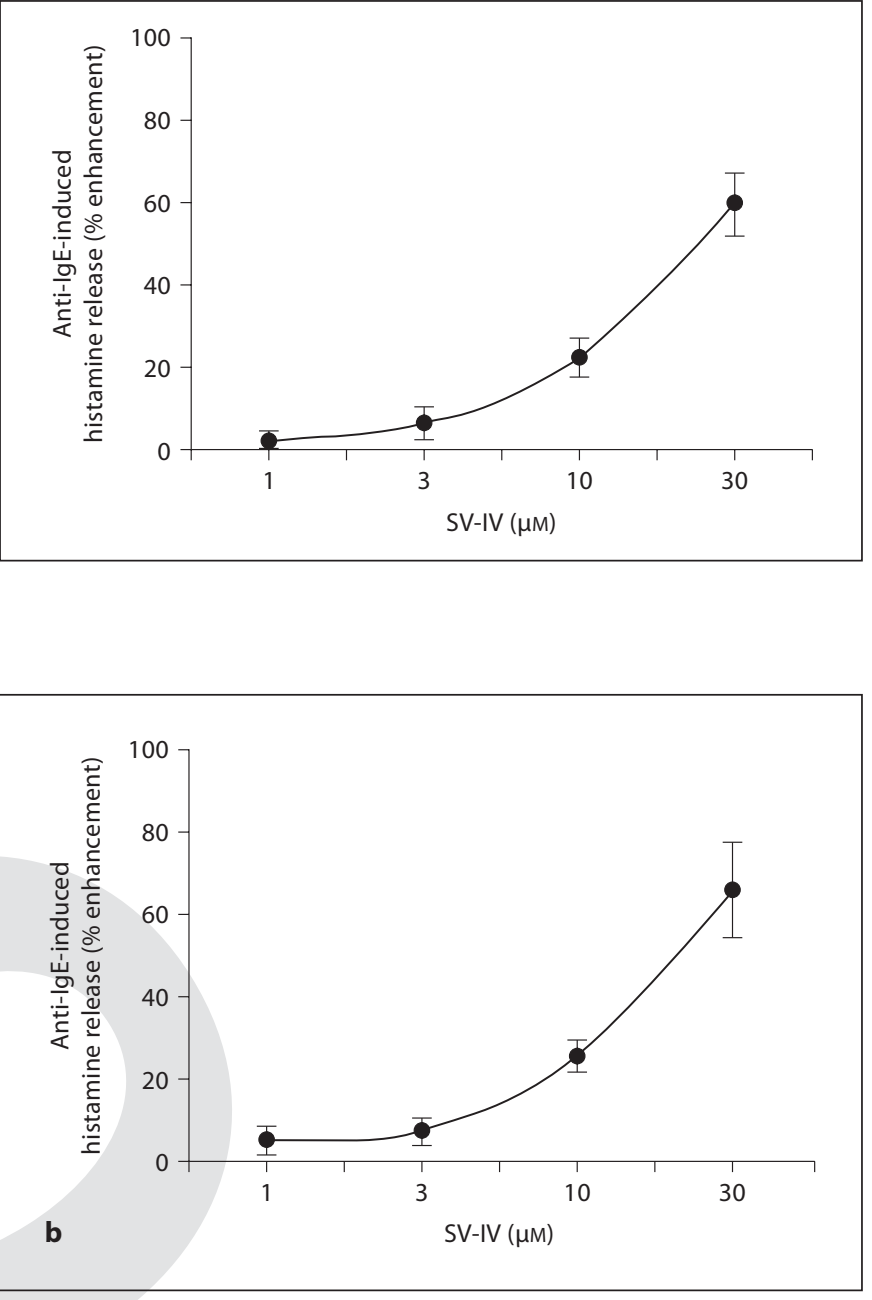

termination. b Effect of preincubation $\left(10 \mathrm{~min}\right.$ at $\left.37^{\circ} \mathrm{C}\right)$ with increasing concentrations $(1-30 \mu \mathrm{M})$ of SV-IV on histamine release from HLMCs induced by anti-lgE (6 nM): each point represents the mean of duplicate determinations from a typical experiment out of 5 performed with similar results.

more physiological model than the human leukemic mast cell line HMC-1.

Figure $4 \mathrm{a}$ shows that a 1-30 $\mu \mathrm{M}$ SV-IV induced a significant dose-dependent release of histamine in these cells $(2.5 \pm 0.6 \%$ at $1 \mu \mathrm{M} \mathrm{SV-IV;} 32.7 \pm 3.4 \%$ at $30 \mu \mathrm{M}$ SV-IV).

Furthermore, to investigate whether SV-IV was able to potentiate histamine release induced by anti-IgE in HLMCs, cells were first preincubated with 1-30 $\mu \mathrm{M}$ SVIV and then stimulated with $6 \mathrm{nM}$ anti-IgE. The data obtained show that SV-IV was able to potentiate (synergistic effect) the release of histamine induced by anti-IgE in the 
target cells only at its highest concentrations (fig. 4b). The concentrations of SV-IV used did not induce spontaneous LDH release from HLMCs (data not shown).

\section{Genistein Does Not Inhibit SV-IV-Induced Histamine} Release

To assess whether SV-IV-induced histamine release from basophils was tyrosine kinase (TK)-dependent, we tested the effects of genistein, a TK inhibitor, on SV-IVinduced degranulation.

Figure 5 shows the results from 3 experiments in which basophils were preincubated $\left(30 \mathrm{~min}\right.$ at $\left.37^{\circ} \mathrm{C}\right)$ with optimal concentrations of genistein $(30 \mu \mathrm{M})$ before challenge $\left(45 \mathrm{~min}\right.$ at $\left.37^{\circ} \mathrm{C}\right)$ with SV-IV $(10-30 \mu \mathrm{M})$ or anti-IgE $(0.6$ $\mathrm{nM})$. In none of the experiments did genistein cause inhibition of histamine release induced by SV-IV. In control experiments, genistein inhibited anti-IgE-induced histamine release. Similar results were obtained with HLMCs (data not shown).

These results are in line with the hypothesis that SVIV activates FceRI+ cells independently from tyrosine kinase activity.

\section{SV-IV Does Not Influence the Expression of Cytokine}

mRNA in HMC-1 Cells

To verify whether SV-IV regulates the synthesis of anti-inflammatory and immunosuppressive cy tokines in HMC-1, the real-time PCR was used to evaluate the effect of $30 \mu \mathrm{M}$ SV-IV on IL-10 and TGF- $\beta_{1}$ mRNA expression. SV-IV was unable to upregulate expression after $16 \mathrm{~h}$ incubation, whereas the phorbol myristate acetate (PMA; $4 \mathrm{nM}$ ) and the calcium ionophore A23187 (200 nM), used in combination as positive control, induced marked expression of these cytokine mRNAs (fig. 6a).

To examine whether SV-IV regulates the synthesis of some immunostimulatory and proinflammatory cytokines in HMC-1 cells, the effect of $30 \mu \mathrm{M}$ SV-IV on IL-13 and TNF- $\alpha$ mRNA expression was evaluated by real-time PCR. SV-IV was unable to upregulate the mRNA expression of these cytokines after $16 \mathrm{~h}$ of incubation. The positive control (PMA + A23187), in contrast, induced marked expression of the same cytokine mRNAs (fig. 6b).

The concentrations of SV-IV used did not induce spontaneous LDH release from HMC-1 cells after $16 \mathrm{~h}$ treatment (data not shown).

\section{SV-IV Does Not Modify VEGF-A mRNA Expression in HMC-1 Cells}

To determine whether SV-IV regulates the synthesis of proangiogenic mediators in HMC-1 cells, real-time

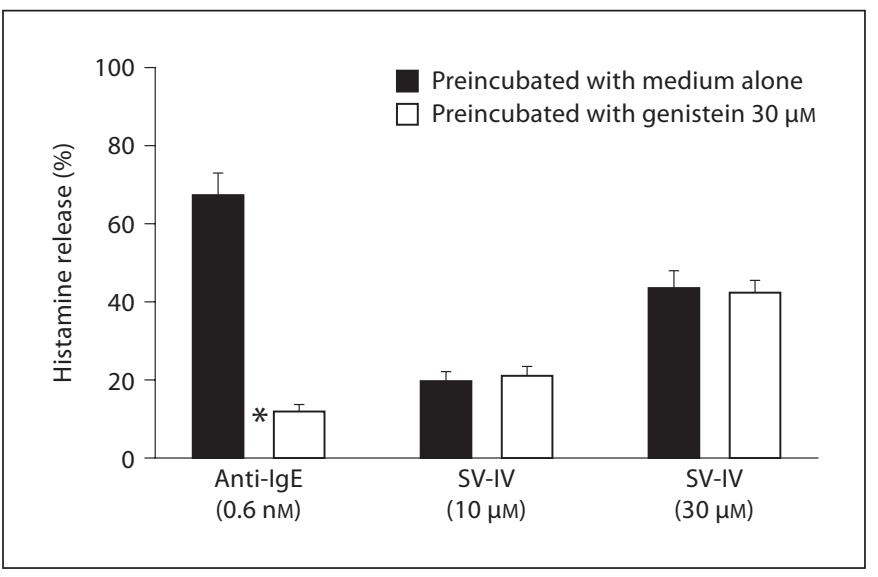

Fig. 5. Effect of genistein on SV-IV-induced histamine release from basophils. Results of 3 independent experiments in which basophils were preincubated $\left(30 \mathrm{~min}\right.$ at $\left.37^{\circ} \mathrm{C}\right)$ with optimal concentrations of genistein $(30 \mu \mathrm{M})$ before challenge $\left(45 \mathrm{~min}\right.$ at $\left.37^{\circ} \mathrm{C}\right)$ with SV-IV $(10-30 \mu \mathrm{M})$ or anti-IgE $(0.6 \mathrm{nM})$. In none of the experiments did genistein cause inhibition of histamine release induced by SV-IV. As a control, genistein was able to inhibit antiIgE-induced histamine release. Values are the means \pm SEM of 3 experiments with different cell preparations. ${ }^{*} \mathrm{p}<0.05$ versus untreated (control) cells.

PCR was used to assess the effect of $30 \mu \mathrm{M}$ SV-IV on VEGF-A mRNA expression. SV-IV did not modify VEGF-A mRNA expression after 16 and $24 \mathrm{~h}$ of incubation, whereas $4 \mathrm{nM}$ PMA and $200 \mathrm{nM}$ A23187, used in combination as positive control, induced a marked expression of this mRNA (fig. 6c).

\section{SV-IV Does Not Influence the TGF- $\beta_{1}$ Release from HMC-1 Cells}

The data above reported demonstrate that SV-IV did not induce TGF- $\beta_{1}$ mRNA expression in HMC-1 cells. We also evaluated the effect of 1-30 $\mu \mathrm{M}$ SV-IV on TGF$\beta_{1}$ release from the same cells after 24-hour incubation. SV-IV was unable to induce TGF- $\beta_{1}$ release from HMC-1 cells, whereas PMA (4 nM) and A23187 (200 nM), used in combination as a positive control, induced strong upregulation of this cytokine release (fig. 7).

The concentrations of SV-IV used did not induce spontaneous LDH release from HMC-1 cells after 24hour treatment (data not shown).

\section{SV-IV Does Not Influence the VEGF-A Release from} Basophils

We also evaluated the effect of 1-30 $\mu \mathrm{M}$ SV-IV on VEGF-A release from human basophils after 4-hour in- 


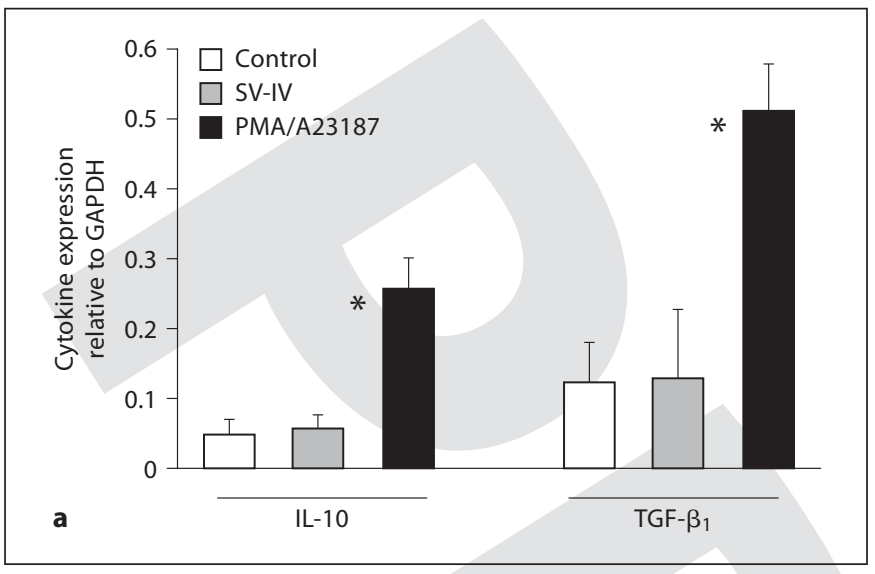

Fig. 6. Real-time quantitative RT-PCR analysis of IL-10 and TGF$\beta_{1}$ (a), IL-13 and TNF- $\alpha$ mRNA expression (b) in HMC-1 cells cultured for $16 \mathrm{~h}$ with medium alone, SV-IV $(30 \mu \mathrm{M})$ or PMA (4 nM)/A23187 (200 nM). RT-PCR was performed with SYBR Green technology as described in Materials and Methods. Cytokine expression was evaluated as times increase versus GAPDH. The data are the means \pm SEM of 3 experiments. ${ }^{*} p<0.05$ versus untreated (control) cells. c Real-time quantitative RT-PCR analysis of VEGF-A mRNA expression in HMC-1 cells cultured with medium alone, SV-IV (30 $\mu \mathrm{M})$ or PMA (4 nM)/A23187 (200 nM) for 16 or $24 \mathrm{~h}$. Cytokine expression was evaluated as times increase versus GAPDH. The data are the means \pm SEM of 3 experiments. ${ }^{*} \mathrm{p}<0.05$ versus untreated (control) cells.

cubation. SV-IV was unable to induce VEGF-A release from these cells whereas anti-IgE $(0.6 \mathrm{nM})$, used as a positive control, induced upregulation of this cytokine release (fig. 8).

No increment in spontaneous LDH release was shown by basophils after $4 \mathrm{~h}$ of incubation with SV-IV.

\section{SV-IV Does Not Upregulate CD203c, an in vitro \\ Marker of FceRI+ Cell Activation}

CD203c, a type II transmembrane protein, has been described to be selectively expressed on basophils, mast cells and their CD34+ progenitors. As CD203c is rapidly upregulated after allergen challenge in sensitized patients, it has been proposed as a new tool for allergy diagnosis [49]. We tested the effects of SV-IV protein (1-hour treatment, $30 \mu \mathrm{M}$ ) on CD203c expression on human basophils. The results of three independent experiments show that no CD203c overexpression can be observed after SV-IV treatment of basophils (fig. 9). Similar results were also found by assessing the expression of CD63 [50] in the same cell system (data not shown).

SV-IV Induces Histamine Release
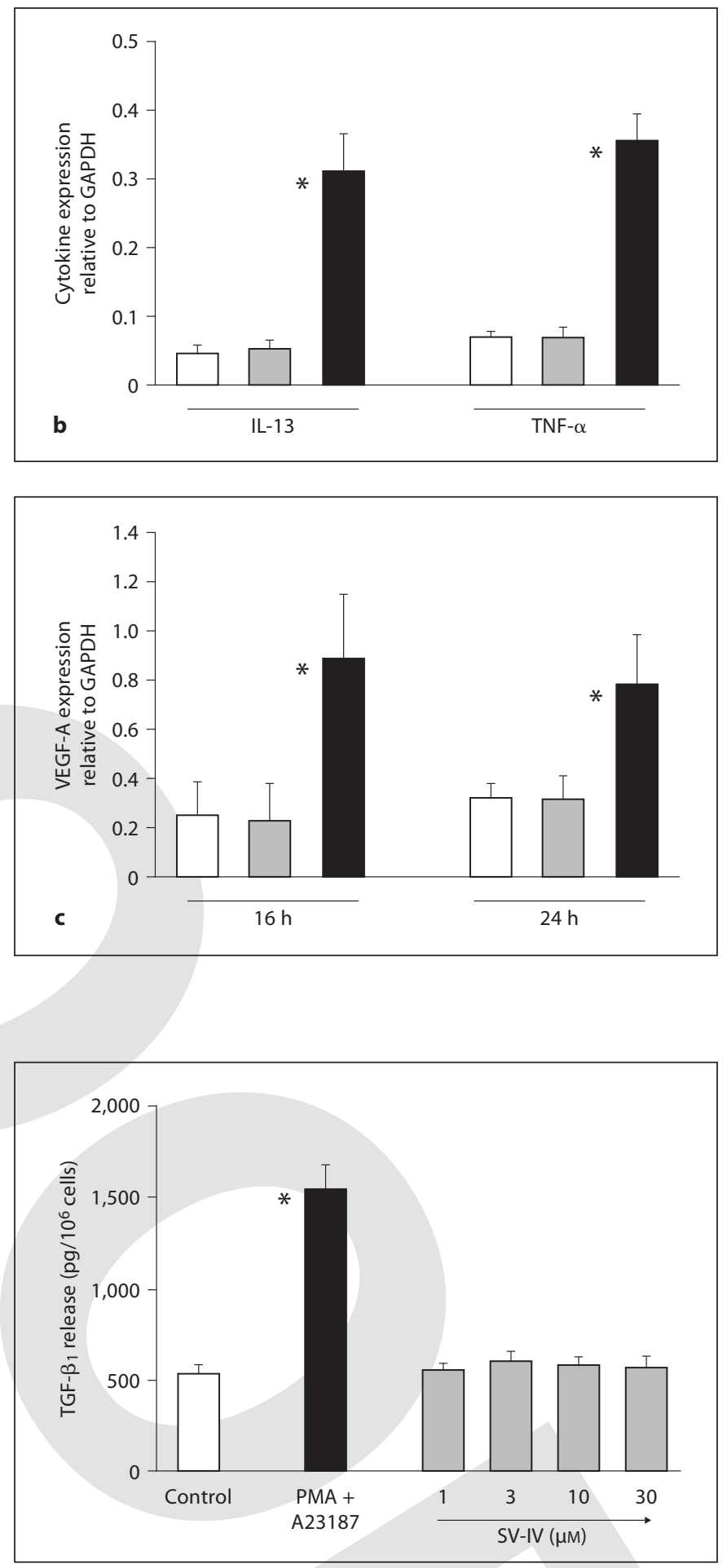

Fig. 7. SV-IV does not induce TGF- $\beta_{1}$ release from HMC-1 cells. One million cells per sample were incubated for $24 \mathrm{~h}$ without (control) or with increasing concentrations of SV-IV $(1-30 \mu \mathrm{M})$ or with PMA (4 nM)/A23187 (200 nM). Supernatants were collected at each time point. TGF- $\beta_{1}$ was determined by ELISA. Values are expressed as the means \pm SEM of 3 different experiments. ${ }^{*} \mathrm{p}<$ 0.05 versus untreated (control) cells.

Int Arch Allergy Immunol 125 


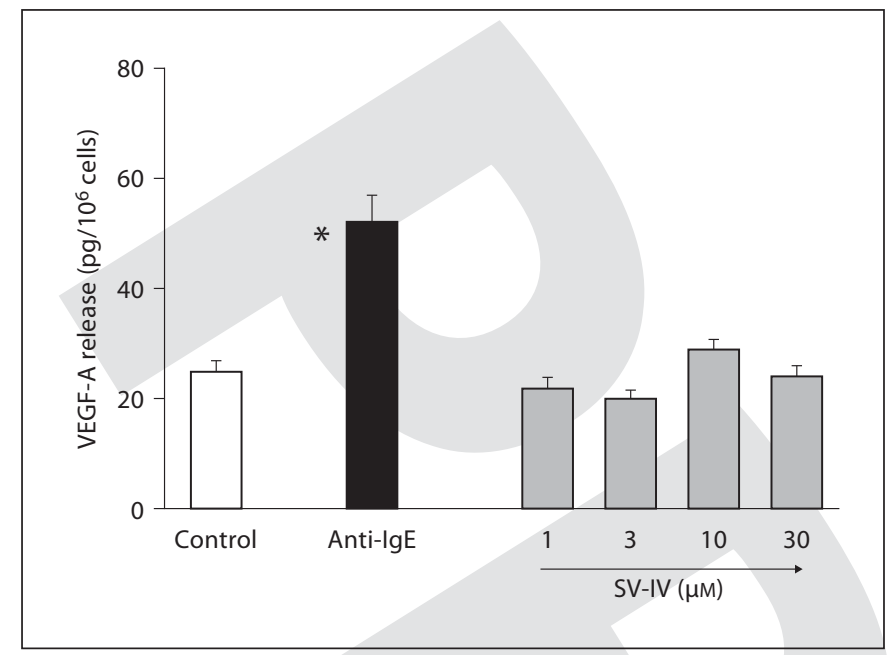

Fig. 8. SV-IV does not induce VEGF-A release from basophils. Five hundred cells per sample were incubated for $4 \mathrm{~h}$ without (control) or with increasing concentrations of SV-IV $(1-30 \mu \mathrm{M})$ or with Anti-IgE (0.6 nM). Supernatants were collected at each time point. VEGF-A was determined by ELISA. Values are expressed as means \pm SEM of 3 different experiments. ${ }^{*} \mathrm{p}<0.05$ versus untreated (control) cells.

\section{Discussion}

We demonstrated that SV-IV promotes the release of significant levels of histamine (degranulation effect) from mast cells and basophils without inducing other responses including eicosanoid generation, cytokine production and chemotaxis. This unusual response for a normal secretagogue was in part expected and consistent with the known biochemical and biological activities of SV-IV on its target cells such as: (a) the block of arachidonate cascade via $\mathrm{PLA}_{2}$ inhibition [19, 21]; (b) the modulation of cytokine generation in a positive or negative manner [13, 22-24]; (c) the inhibition of human leukocyte chemotaxis [20].

Considering (a) the multifunctionality of SV-IV, (b) its ability to interact with the plasma membranes of different target cells ( $\mathrm{T}, \mathrm{B}$, and NK cells, macrophages/monocytes, cancer cells, FceRI+ cells, blastomers, spermatozoa, platelets) and (c) its intrinsically disordered structure, a protein like SV-IV needs a large plasticity to efficiently interact with the different targets [10]. With FceRI+ cell plasma membranes, SV-IV attained a particular structure more appropriate to produce a degranulation effect rather than de novo synthesis of mediators. It has been shown that when bound to the plasma mem-

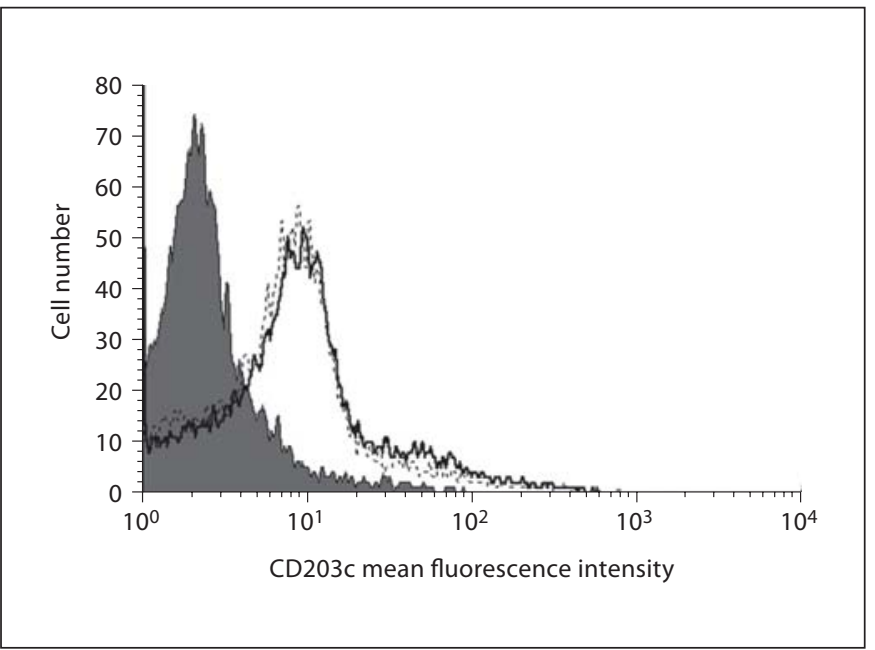

Fig. 9. SV-IV does not induce up-regulation of CD203c on basophil surface. Staining was performed at $4^{\circ} \mathrm{C}$ for 30 min with 10 $\mu \mathrm{l} / 200 \mu \mathrm{l}$ cell suspensions of the marker antibodies: anti-CD203c$\mathrm{PE}$ and anti-IgE-FITC. The negative controls consisted of isotypematched, directly conjugated nonspecific antibodies. Histograms show CD203c expression on anti-IgE-positive cells. The grey histogram represents the isotype control; the black line shows CD203c basal expression, the dotted line refers to CD203c expression after SV-IV treatment.

brane of resting human monocytes and lymphocytes, SVIV stimulates these cells to release de-novo-synthesized proinflammatory cytokines [13]. In contrast, the latter event does not occur when SV-IV is bound to the surface of Fc $\varepsilon$ RI+ cells.

The time course of histamine release induced by SVIV in basophils was significantly slower than that induced by anti-IgE. This finding is not so unusual because such slow kinetics is also known to be induced in basophils by other stimuli (e.g. C5a, TPA), thus suggesting mechanisms of action different from that induced by anti-IgE [51, 52].

The possibility that histamine release induced by SVIV could be related to a generic toxicity or a proapoptotic effect of SV-IV on its target cells is, however, ruled out by several published data showing that SV-IV is nontoxic and strongly antiapoptotic $[17,28]$. In addition, treatment of FceRI+ cells with 10-30 $\mu$ M SV-IV in short- and longtime incubations does not produce any significant change in cell viability, as measured by the LDH assay. The finding that SV-IV operates on human basophils by a noncytotoxic mechanism is also supported by the fact that its histamine-releasing activity is temperature dependent. Finally, the ability of SV-IV to allow survival of dividing 
murine zygotes up to the blastocyst stage in a culture medium nonpermissive for embryo development further supports these findings [17].

Neither CD203c nor CD63 were upregulated by SV-IV treatment of human basophils. This finding suggests that SV-IV, like diclofenac and other NSAIDs, stimulates FceRI+ cell degranulation without IgE intervention, thus promoting a pseudoallergic reaction in which this protein does not act as an IgE-interacting allergen [50].

Treatment of SV-IV-target cells with the fluoresceinated or iodinated protein demonstrated the binding of this protein to their surface $[11,17,20,24]$. Furthermore, the molecular signaling of the antiapoptotic mechanism of SV-IV has been related to the protein tyrosine phosphorylation cascade induced by a PTK activity triggered by SV-IV binding to its lymphocyte plasma membrane putative receptors [17]. On the contrary, as far as histamine release from FceRI+ cells is concerned, SV-IV does not seem to operate via TK signaling, as suggested by our genistein experiments.

At the present time, on the basis of our data, the protein SV-IV could be considered an incomplete secretagogue able to trigger histamine release from FceRI+ cells without stimulating the production or the release of other mediators $[53,54]$.

Much work is still needed, however, for a better definition of the mechanism of action of SV-IV-stimulated histamine release from FceRI+ cells. A receptor-independent but membrane-assisted process induced by cationic secretagogues and involving $\mathrm{G}$ proteins may deserve investigation in these cells.

The presence of the immunosuppressive and antiapoptotic SV-IV in uterus at the implantation site [28] could contribute to the definition of the immunotolerant characteristics of the site. However, evidence that SV-IV is present in this location is only circumstantial: (a) SVIV is present in rat ejaculated semen in free and spermbound form; (b) an SV-IV immunorelated protein has been found in rat uterine lysates and in human seminal plasma $[1,14-16,55,56]$. In rats, this speculation is supported by experiments demonstrating that the immunogenicity of blastocyst blastomeres is suppressed (about 80\%) by SV-IV [28]. These SV-IV-induced immunosuppressive findings are in line with: (a) the ability of SV-IV to activate mast cell and basophil degranulation with release of immunosuppressive and antiapoptotic histamine [38 and our data reported in this article]; (b) the ability of SV-IV to protect mouse zygote growth up to the blastocyst stage [17]; (c) other data showing the critical role of oxidative stress in jeopardizing embryo survival during early development [57], and (d) the protective effect of SV-IV on some target cancer cells (Raji, K562, DAUDI) against NK cytotoxicity [28]. In conclusion, when analyzed in the context of other biological features of SV-IV, these findings provide a better understanding of its immune regulatory functions and also raise the possibility of a contributory role (at least in rodents) in the multifactorial orchestration at the uterine implantation site of maternal immunotolerance and blastocyst survival.

Furthermore, other data demonstrate that human embryos at the preimplantation stage synthesize and secrete a protein, named embryo-derived histamine-releasing factor (EHRF), capable of inducing the release of histamine from basophils and preimplantation uterine-derived mast cells $[39,58-60]$. On the basis of these findings and by considering the immunosuppressive activity of histamine, the authors proposed a novel implantation model. This model suggests that the local secretion of histamine in vivo by uterine FceRI+ cells, alone or in cooperation with other factors and/or mechanisms, could play a crucial role in preventing maternal immunorejection of the embryo allograft at the implantation stage $[39,58-$ 60]. The immunosuppressive features of SV-IV could significantly contribute to this model.

\section{Acknowledgements}

We are very grateful to Dr. G. Pontoni for critical reading of the manuscript, to Mr. S. Baiano and Mr. F. Moscatiello for their skillful technical assistance, and to Mrs. Mary Victoria Freda for reviewing the English.

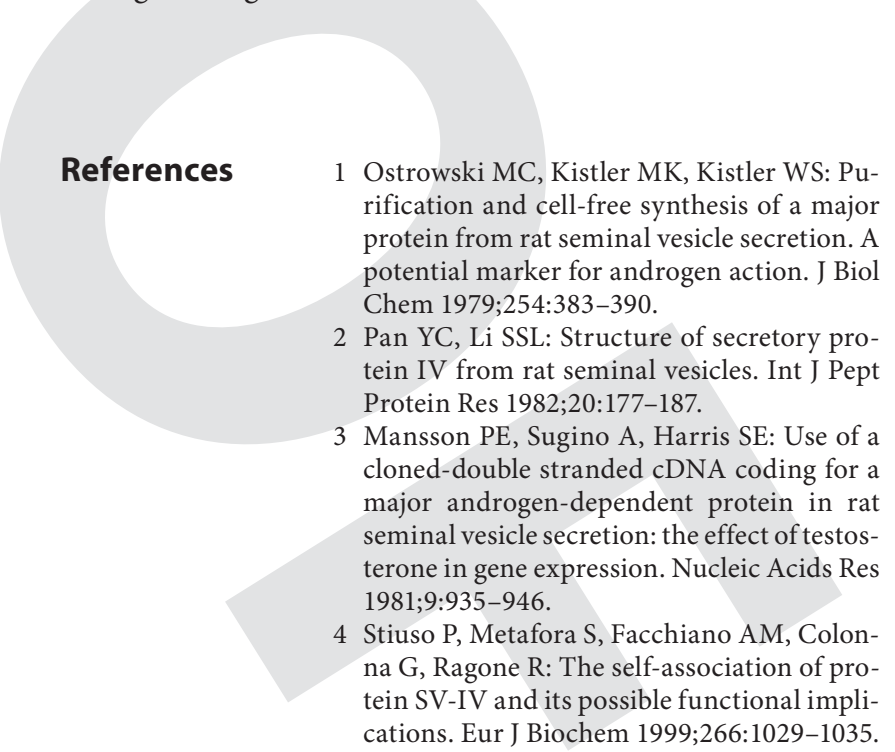

Int Arch Allergy Immunol 125 
5 Caporale C, Caruso C, Colonna G, Facchiano A, Ferranti P, Mamone G, Picariello G, Colonna F, Metafora S, Stiuso P: Structural properties of the protein SV-IV. Eur J Biochem 2004;271:263-271.

6 Harris SE, Mansson PE, Tully DB, Burkhart B: Seminal vesicle secretion IV gene: allelic difference due to a series of 20-base-pair direct tandem repeats within an intron. Proc Natl Acad Sci USA 1983;80:6460-6464.

7 Kandala C, Kistler MK, Lawther RP, Kistler WS: Characterization of a genomic clone for rat seminal vesicle secretory protein IV. Nucleic Acids Res 1983;11:3169-3186.

8 McDonald C, Williams L, McTurck P, Fuller F, McIntosh E, Higgins S: Isolation and characterisation of genes for androgen-responsive secretory proteins of rat seminal vesicles. Nucleic Acids Res 1983;11:917-930.

9 D’Ambrosio E, Del Grosso N, Ravagnan G, Peluso G, Metafora S: Cloning and expression of the rat genomic DNA sequence coding for the secreted form of the protein SVIV. Bull Mol Biol Med 1993;18:215-223.

10 Vilasi S, Ragone R: Abundance of intrinsic disorder in SV-IV, a multifunctional androgen-dependent protein secreted from rat seminal vesicle. FEBS J 2008;275:763-774

11 Stiuso P, Metafora S, Facchiano AM, Colonna $G$, Ragone R: The self-association of protein SV-IV and its possible functional implications. Eur J Biochem 1999;266:10291035.

12 Caporale C, Caruso C, Colonna G, Facchiano A, Ferranti P, Mamone G, Picariello G Colonna F, Metafora S, Stiuso P: Structural properties of the protein SV-IV. Eur J Biochem 2004;271:263-271.

13 Tufano MA, Porta R, Farzati B, Di Pierro P, Rossano F, Catalanotti P, Baroni A, Metafora S: Rat seminal vesicle protein SV-IV and its transglutaminase-synthesized polyaminated derivative Spd2-SV-IV induce cytokine release from human resting lymphocytes and monocytes in vitro. Cell Immunol 1996; 168:148-157.

14 Abrescia P, Lombardi G, De Rosa M, Quagliozzi L, Guardiola J, Metafora S: Identification and preliminary characterization of a sperm-binding protein in normal human semen. J Reprod Fertil 1985;73:71-77.

15 Metafora S, Facchiano F, Facchiano A, Esposito C, Peluso G, Porta R: Homology between rabbit uteroglobin and the rat seminal vesicle sperm binding protein: prediction of structural features of glutamine substrates for transglutaminase. J Prot Chem 1987;6: 353-359.

16 Metafora S, Lombardi G, De Rosa M, Quagliozzi L, Ravagnan G, Peluso G, Abrescia P: Protein family immunorelated to a spermbinding protein and its regulation in human semen. Gamete Res 1987;16:229-241.
17 Morelli F, Peluso G, Petillo O, Giannattasio A, Filosa S, Motta CM, Tammaro S, Zatterale A, Calzone R, Budillon A, Carteni M, De Maria S, Costanza MR, Nigro A, Petrazzuolo M, Buommino E, Rizzo M, Capasso G, Baiano S, Moscatiello F, Ravagnan G, Fuggetta MP, Tajana G, Stiuso P, Metafora BM, Metafora $\mathrm{V}$, Metafora $\mathrm{S}$ : The immunomodulatory protein SV-IV protects serum-deprived cells against apoptosis but not against G0/G1 arrest: possible implications for the survival of implanting embryo. J Cell Physiol 2007;212: 610-625.

18 Galdiero F, Tufano MA, De Martino L, Capasso C, Porta R, Ravagnan G, Peluso G, Metafora S: Inhibition of macrophage phagocytic activity by SV-IV, a major protein secreted from the rat seminal vesicle epithelium. J Reprod Immunol 1989;16:269-284.

19 Metafora S, Peluso G, Persico P, Ravagnan G, Esposito C, Porta R: Immunosuppressive and anti-inflammatory properties of a major protein secreted from the epithelium of the rat seminal vesicles. Biochem Pharmacol 1989;38:121-131.

20 Metafora S, Porta R, Ravagnan G, Peluso G, Tufano MA, De Martino L, Ianniello $R$, Galdiero F: Inhibitory effect of SV-IV, a major protein secreted from the rat seminal vesicle epithelium, on phagocytosis and chemotaxis of human polymorphonuclear leukocytes. J Leukoc Biol 1989;46:409-416.

21 Camussi G, Tetta C, Bussolino F, Metafora S, Peluso G, Esposito C, Porta R: An anti-inflammatory protein secreted from the rat seminal vesicle epithelium inhibits the synthesis of platelet-activating factor and the release of arachidonic acid and prostacyclin. Eur J Biochem 1990;192:481-485.

22 Vuotto ML, Peluso G, Mancino D, Colonna G, Facchiano A, Ielpo MT, Ravagnan G, Metafora S: Inhibition of interleukin-1 release and activity by the rat seminal vesicle protein SV-IV. J Leukoc Biol 1993;5:32143222.

23 Peluso G, Porta R, Esposito C, Tufano MA, Toraldo R, Vuotto ML, Ravagnan G, Metafora S: Suppression of rat epididymal sperm immunogenicity by a seminal vesicle secretory protein and transglutaminase both in vivo and in vitro. Biol Reprod 1994;50:593602 .

24 Romano-Carratelli C, Bentivoglio C, Nuzzo I, Benedetto N, Buommino E, Cozzolino A, Cartenı' M, Morelli F, Costanza MR, Metafora B, Metafora V, Metafora S: Effect of protein SV-IV on experimental Salmonella enterica serovar typhimurium infection in mice. Clin Diagn Lab Immunol 2002;9:115125.

25 Metafora V, Franco P, Massa O, Morelli F Stiuso P, Ferranti P, Mamone G, Malorni A, Stoppelli MP, Metafora S: Phosphorylation of seminal vesicle protein IV on Ser58 enhances its peroxidase-stimulating activity. Eur J Biochem 2001;268:3858-3869.
26 Metafora V, Stiuso P, Ferranti P, Giannattasio A, Dicitore A, Ravagnan G, De Maria S, Pontoni G, Cartenì M, Metafora S: In vitro stimulatory effect of anti-apoptotic seminal vesicle protein 4 on purified peroxidase enzymes. FEBS J 2008;275:3870-3883.

27 Romano-Carratelli C, Galdiero M, Nuzzo I, Bentivoglio C, Porta R, Peluso G, Ravagnan G, Metafora S: In vivo inhibition of cell-mediated and humoral immune responses to cellular antigens by SV-IV, a major protein secreted from the rat seminal vesicle epithelium. J Reprod Immunol 1995;28:15-30.

28 Fuggetta MP, Lanzilli G, Cottarelli A, Ravagnan $G$, Cartenì M, De Maria S, Metafora BM, Metafora V, Metafora S: Anti-apoptotic seminal vesicle protein IV inhibits cell-mediated immunity. J Reprod Immunol 2008; 78:85-93.

29 Marone G, Triggiani M, Genovese A, de Paulis A: Role of human mast cells and basophils in bronchial asthma. Adv Immunol 2005;88: 97-160.

30 Galli SJ, Nakae S, Tsai M: Mast cells in the development of adaptive immune responses. Nat Immunol 2005;6:135-142.

31 Galli SJ, Kalesnikoff J, Grimbaldeston MA, Piliponsky AM, Williams CM, Tsai M: Mast cells as 'tunable' effector and immunoregulatory cells: recent advances. Annu Rev Immunol 2005;23:749-786.

32 Ryan JJ, Kashyap M, Bailey D, Kennedy S, Speiran K, Brenzovich J, Barnstein B, Oskeritzian C, Gomez G: Mast cell homeostasis: a fundamental aspect of allergic disease. Crit Rev Immunol 2007;27:15-32.

33 Metcalfe DD, Baram D, Mekori YA: Mast cells. Physiol Rev 1997;77:1033-1079.

34 Marone G, Triggiani M, de Paulis A: Mast cells and basophils: friends as well as foes in bronchial asthma? Trends Immunol 2005; 26:25-31.

35 de Paulis A, Prevete N, Fiorentino I, Walls AF, Curto M, Petraroli A, Castaldo V, Ceppa P, Fiocca R, Marone G: Basophils infiltrate human gastric mucosa at sites of Helicobacter pylori infection, and exhibit chemotaxis in response to $H$. pylori-derived peptide Hp(2-20). J Immunol 2004;172:7734-7743.

36 MacGlashan D Jr: Histamine: a mediator of inflammation. J Allergy Clin Immunol 2003; 112:S53-S59.

37 Mellqvist UH, Hansson M, Brune M, Dahlgren C, Hermodsson S, Hellstrand K: Natural killer cell dysfunction and apoptosis induced by chronic myelogenous leukemia cells: role of reactive oxygen species and regulation by histamine. Blood 2000;96:19611968.

38 Hansson M, Hermodsson S, Brune M, Mellqvist UH, Naredi P, Betten A, Gehlsen KR, Hellstrand K: Histamine protects T cells and natural killer cells against oxidative stress. J Interferon Cytokine Res 1999; 19:11351144.

Prevete et al. 
39 Cocchiara R, Di Trapani G, Azzolina A, Albeggiani G, Geraci D: Early embryonic histamine-releasing factor: a new model for human implantation. Hum Reprod 1986; 1: 445-447.

40 Beer DJ, Rocklin RE: Histamine-induced suppressor-cell activity. J Allergy Clin Immunol 1984;73:439-452.

41 Beer DJ, Matloff SM, Rocklin RE: The influence of histamine on immune and inflammatory responses. Adv Immunol 1984;35: 209-268.

42 de Paulis A, De Palma R, Di Gioia L, Carfora M, Prevete N, Tosi G, Accolla RS, Marone G: Tat protein is an HIV-1-encoded $\beta$-chemokine homolog that promotes migration and up-regulates CCR3 expression on human Fc epsilon RI+ cells. J Immunol 2000;165:71717179.

43 Porta R, Esposito C, Metafora S, Malorni A, Pucci P, Siciliano R, Marino G: Mass spectrometric identification of the amino donor and acceptor sites in a transglutaminase protein substrate secreted from rat seminal vesicles. Biochemistry 1991;30:3114-3120.

44 Yin ET, Galanos C, Kinsky S, Bradshaw RA, Wessler S, Luderig O, Sarmiento MF: Picogram-sensitive assay for endotoxin: gelation of Limulus polyphemus blood cell lysate induced by purified lipopolysaccharides and lipid A from Gram-negative bacteria. Biochim Biophys Acta 1972;261:284-289.

45 Rubin BY, Anderson SL, Sullivan SA, Williamson BD, Carswell EA, Old L: Purification and characterization of a human tumor necrosis factor from the LuKII cell line. Proc Natl Acad Sci USA 1985;82:6637-6641.

46 Ma Y, Zeng S, Metcalfe DD, Akin C, Dimitrijevic S, Butterfield JH, McMahon G, Longley BJ: The c-KIT mutation causing human mastocytosis is resistant to STI571 and other KIT kinase inhibitors; kinases with enzymatic site mutations show different inhibitor sensitivity profiles than wild-type kinases and those with regulatory-type mutations. Blood 2002;99:1741-1744.
47 Florio G, Petraroli A, Patella V, Triggiani M, Marone G: The immunoglobulin superantigen-binding site of HIV-1 gp120 activates human basophils. AIDS 2000;14:931-938.

48 de Paulis A, Prevete N, Fiorentino I, Rossi FW, Staibano S, Montuori N, Ragno P, Longobardi A, Liccardo B, Genovese A, Ribatti D, Walls AF, Marone G: Expression and functions of the vascular endothelial growth factors and their receptors in human basophils. J Immunol 2006;177:7322-7331.

49 Nagao M, Hiraguchi Y, Hosoki K, Tokuda R, Usui T, Masuda S, Yamaguchi M, Fujisawa T: Allergen-induced basophil CD203c expression as a biomarker for rush immunotherapy in patients with Japanese cedar pollinosis. Int Arch Allergy Immunol 2008;146(suppl 1):47-53.

50 Malbrán A, Yeyati E, Rey GL, Galassi N: Diclofenac induces basophil degranulation without increasing CD63 expression in sensitive patients. Clin Exp Immunol 2007;147: 99-105.

51 Dahinden CA, Kurimoto J, Baggiolini M, Dewald B, Walz A: Histamine and sulfidoleukotriene release from human basophils: different effects of antigen, anti-IgE, C5a, $\mathrm{f}$ Met-Leu-Phe and the novel neutrophil-activating peptide NAF. Int Arch Allergy Appl Immunol 1989;90:113-118.

52 Schleimer RP, Gillespie E, Lichtenstein LM: Release of histamine from human leukocytes stimulated with the tumor-promoting phorbol diesters. I. Characterization of the response. J Immunol 1981;126:570-574.
53 Genovese A, Stellato C, Patella V, Lamparter-Schummert B, de Crescenzo G, Adt M, Marone G: Contrast media are incomplete secretagogues acting on human basophils and mast cells isolated from heart and lung, but not skin tissue. Int J Clin Lab Res 1996; 26:192-198.

54 Patella V, Ciccarelli A, Lamparter-Schummert B, de Paulis A, Adt M, Marone G: Heterogeneous effects of protamine on human mast cells and basophils. Br J Anaesth 1997; 78:724-730.

55 Paonessa G, Metafora S, Tajana G, Abrescia P, De Santis A, Gentile V, Porta R: Transglutaminase-mediated modifications of the rat sperm surface in vitro. Science 1984;226: 852-855.

56 Manco G, Abrescia P: A major secretory protein from rat seminal vesicle binds ejaculated spermatozoa. Gamete Res 1988;21:71-84.

57 Guerin P, El Mouatassim S, Menezo Y: Oxidative stress and protection against reactive oxygen species in the pre-implantation embryo and its surroundings. Hum Reprod Update 2001;7:175-189.

58 Cocchiara R, Di Trapani G, Azzolina A, Albeggiani G, Ciriminna R, Cefalu E, Cittadini E, Geraci D: Isolation of a histamine releasing factor from human embryo culture medium after in-vitro fertilization. Hum Reprod 1987;2:341-344.

59 Cocchiara R, Albeggiani G, Di Trapani G, Azzolina A, Lampiasi N, Cervello G, Geraci D: Dispersal of rat uterine mast cells and their functional response to an embryo-derived histamine releasing factor: a possible model for embryo implantation. J Reprod Immunol 1988;14:191-201.

60 Cocchiara R, Lampiasi N, Albeggiani G, Azzolina A, Bongiovanni A, Gianaroli L, Di Blasi F, Geraci D: A factor secreted by human embryo stimulates cytokine release by uterine mast cell. Mol Hum Reprod 1996;2:781791.

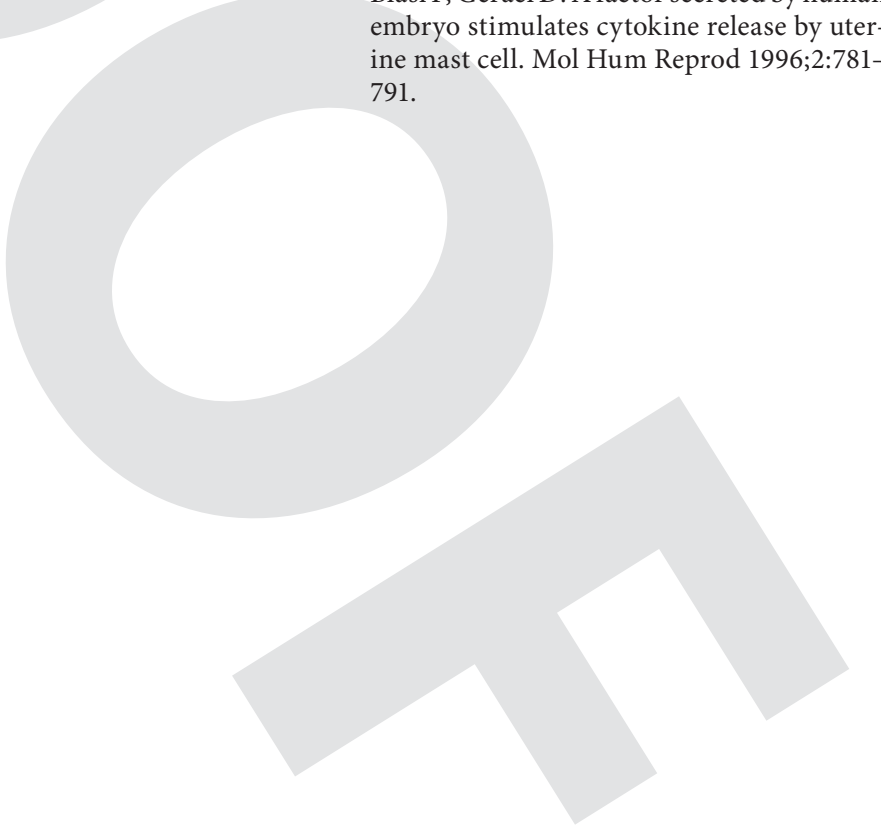

